\title{
A história da normatização contábil americana com ênfase na mundial
}

\author{
Rodrigo Antônio Chaves da Silva ${ }^{1}$
}

Recibido: 11 de junho de 2019

Aprobado: 14 de julho de 2019

Silva, R. A. C. da. (2019). A história da normatização contábil americana com ênfase na mundial. Revista Activos, 17(2), 45-91. DoI: https://doi. org $/ 10.15332 / 25005278 / 5732$

\footnotetext{
1 Contador; especialista em gestão econômica; professor universitário; perito judicial; ganhador do prêmio internacional da história da Contabilidade prof. Martim Noel Monteiro (2007-2008), do prêmio internacional de contabilidade financeira Luiz Chaves de Almeida (2008-2009-2019) e do prêmio internacional Rogério Fernandes Ferreira (2011); representante único do Brasil no Simpósio Internacional das Fronteiras do Conhecimento Contábil no Peru (julho, 2012) e no Congresso Latino-Americano de Contabilidade na Colômbia (2018), com artigo selecionado para o Congresso Internacional da História da Contabilidade (Ballarat, Austrália, 2015) e para o I Congresso Mundial de Contabilidade Pública (Setúbal, Portugal); participante do Congresso dos Técnicos Oficiais de Contas (Lisboa, 2015) e do Congresso da Associação Espanhola de Contabilidade e Administração de Empresas (2017-2018), jornadas luso-espanholas (2018); professor visitante da Universidade de Huelva (Espanha), do Instituto Superior de Contabilidade e Administração (Lisboa) e da Universidade Pablo de Olavide (Espanha); cidadão honorário de Raul Soares e de Huancayo, no Peru; membro da Associação Científica Internacional Neopatrimonialista, do clube de Balanced Scorecard da Argentina; acadêmico efetivo imortalizado pela Academia de Ciências, Letras e Artes de Manhuaçu e pela Academia Mineira de Ciências Contábeis; autor de 25 livros e mais de 350 artigos técnicos, além de 500 textos na sua página do Facebook e na página Neopatrimonialismo; seus livros publicados pela Juruá Editora podem ser encontrados no site www.jurua.com.br. E-mail: rachavesilva@yahoo.com.br ORCID: https://orcid.org/0000-0002-6536-0424
} 
Clasificación JEL: M41, M49

\section{Resumo}

O movimento normatizador atual apresenta uma história que nos faz compreender melhor a sua condição. Não se pode absorver o entendimento das regras hodiernas sem uma visão do passado. Nesse sentido, o objetivo deste trabalho é expressar algumas abordagens da história das entidades e dos órgãos de emissão das normas dos Estados Unidos da América, com a hipótese de que tal movimento tenha sido forte para relevar o processo de convergência que estamos vivenciando. Como a normatização está em grande destaque, discutir a sua cronologia é necessário, o que torna este trabalho relevante, sendo um dos poucos a explorar o tema. Portanto, pretende-se explicar o fenômeno das normas internacionais a partir de uma pesquisa exploratória, com fundamentação bibliográfica, por ser assunto inclinado à história da contabilidade.

Palavras-chave: divisão da história da normatização americana; história da normatização americana; efeito na normatização mundial.

\section{La historia de la normatividad contable americana con énfasis en la mundial}

\section{Resumen}

El movimiento normativo actual presenta una historia que nos hace comprender mejor su condición. No se puede entender las reglas modernas sin una breve visión del pasado. En este sentido, el propósito del trabajo es presentar algunos enfoques de la historia de las entidades y los órganos de emisión de las normas del país americano, con la hipótesis de que tal movimiento haya sido fuerte para relevar el proceso de convergencia que 
hemos vivenciado. Como la normatividad está en gran relevancia, discutir su cronología es necesario, lo que vuelve este estudio importante, siendo uno de los pocos que exploran el tema. Por lo tanto, se pretende explicar el fenómeno de las normas internacionales desde una investigación exploratoria, con fundamentación bibliográfica, por ser asunto circunscrito a la historia de la Contabilidad.

Palabras clave: división de la historia de la normatividad americana, historia de la normatividad americana, efecto en la normatividad mundial.

\title{
History of the American Accounting Regulation with an Emphasis on Global Regulation
}

\begin{abstract}
The current normative movement has a history that helps us better understand its condition. Modern rules cannot be understood without an overview of the past. In this sense, the purpose of this paper is to introduce some approaches to the history of the entities and bodies that issued the rules of the American country, with the hypothesis that such movement has been strong enough to reveal the process of convergence that we have experienced. As the normativity is of great relevance, it is necessary to discuss its chronology. This gives this study relevance, being one of the few that explores the topic. Therefore, we intend to explain the phenomenon of international regulations from an exploratory research, with a bibliographic basis, as it is a matter limited to the history of accounting.
\end{abstract}

Keywords: division of the history of American normativity, history of American normativity, effect on normativity across the world. 


\section{Introdução}

O fenômeno de normatização ou do movimento regulatório que propõe uma linguagem universal dos negócios tem sido discutido a partir de diversas abordagens. Tem sido caracterizado não só no que diz respeito às suas partes - por consequência à sua formação e influência nas empresas - , ora aceito, ora criticado, mas também como resultado de um processo normativo no âmbito nacional e internacional.

Os conteúdos normativos na atualidade, podemos assim dizer, são colocados como conteúdos prontos e, nos muitos ângulos, oferecem disparates diversos; por sua vez, não são produzidos trabalhos de crítica ou análise a esse respeito, muito menos sobre a sua história.

$\mathrm{Na}$ verdade, os Estados Unidos foram o país que mais atentou para uma regulação. A história do seu progresso, dentro da contabilidade, merece uma consideração, no entanto são poucos os trabalhos com essa visão, por exemplo os de: Sá (1994a, 1994b, 1997, 2008, 2009, 2010) e de Nepomuceno (2002, 2003, 2004) no Brasil; de Casella (2010) na Argentina; de Ferreira (1981, 1983, 2009a, 2009b, 2010), Cravo (2010) e Cravo, Jesus e Antão (2010) em Portugal.

Portanto, o objetivo deste artigo é tratar sobre a história do movimento de normatização norte-americana em apontamentos gerais e, assim, promover conclusões pela averiguação da sua influência no movimento mundial.

O problema a ser investigado é se a finalidade ética e científica da normatização atende ao seu intento considerando a abordagem histórica. Em outras palavras, se a cronologia e os fatos temporais da normatização produziram algum efeito no movimento mundial e se estiveram ligados a uma evolução do uso da informação contábil em obediência aos princípios. São os questionamentos fundamentais que levaram à realização deste trabalho. 
Trata-se de uma pesquisa exploratória, a qual interage com o aprofundamento da investigação histórica, embasada em referencial bibliográfico, para sustentar os argumentos produzidos.

Como saber o que aconteceu é fundamental para se compreender o presente, podemos afirmar que esta pesquisa histórica se justifica por serem pouquíssimas as inquirições que promoveram igual tratamento. Ainda, como o movimento é relevante, torna-se válida a abordagem, considerando a sua atual influência na linguagem dos negócios, a patamares globalizados ou mundiais.

$\mathrm{O}$ artigo se divide em três partes, as quais são fundamentais para compreendermos didaticamente a pesquisa e o desenvolvimento do tema: 1. contexto das normas no âmbito filosófico; 2 divisão das fases da normatização americana; 3. influência do movimento na regularização mundial, observações e conclusões.

\section{O conceito de "normas" e seus objetivos dentro dos princípios da Filosofia}

A palavra "norma", proveniente do latim, expressa o significado de "normal" (Nóbrega, 1959). Portanto, as normas devem vir perseguidas com finalidades normais e com orientações circunspetas sobre os hábitos naturais do ser humano.

Norma, no contexto profissional, nada mais é do que regras sobre as práticas ou os conhecimentos normais que se regulam como padrões e, obviamente, podem se referir a elementos éticos, profissionais e intelectuais.

Existem, pois, normas para a postura comportamental das pessoas, para a formação, para a codificação da prática profissional, para a regulação dos meios para se viver bem e para a sabedoria. Contudo, elas têm uma única base comum de conhecimento filosófico (Teichman e Evans, 2009). O conhecimento é a base da norma, de modo que ela é válida quando se 
estabelecem, em concreto, as causas e os efeitos das coisas, atinando as consequências provindas da sua aplicação.

No âmbito filosófico, Kant (s/d) expunha que as normas são os efeitos dos princípios, os quais são provenientes de leis. Esclareçamos bem: as leis são teoremas ou máximas que estipulam como um fenômeno deve ocorrer constantemente, em uma determinada situação ou atividade, e as normas são regras que se embasam nos princípios.

Portanto, na filosofia, o termo "lei" por vezes se confunde com "princípio", como apontava Poincaré (1924) ao assumir a lei da relatividade como "princípio" da relatividade (por isso, temos a lei ou a teoria kantiana igual ao princípio kantiano). Todavia, não se mescla com "norma", porque esta é uma regra para servir ou orientar uma determinada atividade rotineira.

Sem dúvida, em contabilidade, temos as mesmas convicções, pois existem as leis da contabilidade, relativas aos fenômenos patrimoniais; temos os princípios, que fomentam a forma de registro, demonstração e pensamento fundamental ou conceitual, e temos as normas, que são as regras embasadas nos conceitos (Silva, 2010).

Então, a norma, no aspecto científico e filosófico, é uma regulação ou regras orientadoras, já atestadas pelos princípios e leis da contabilidade, gerados pelas doutrinas ou pelos doutrinadores de nossa ciência.

Por exemplo, se dissermos que, pela teoria doutrinal do personalismo, a pessoa, por mais que se confunda com a empresa, possui nela bens consignados, o que faz diferir a matéria patrimonial da pessoal do proprietário, formando os valores patrimoniais, teremos um conceito definido em teoria que é o da "impessoalidade da coordenação patrimonial", o que dá origem a um princípio: o da célula social ou o da existência do empreendimento, aquele que denominamos de "entidade"2.

2 A palavra "entidade", no inglês “entity", significa "tudo o que existe”. A concepção de "entidade" como sinônimo de "azienda" ou "empreendimento" é vaga, embora seja assim colocada, sem respeitar o literalismo do vocábulo. 
Portanto, os princípios são tirados da teoria, a qual, por sua vez, produz as leis e formam os conceitos básicos, considerados como regras maiores (Sá, 2000). Dessa maneira, normas são orientações para os efeitos da já consagrada tradição doutrinária, a qual aponta a veracidade de nosso conhecimento e de sua expressão, que é a informação.

Assim, a norma, no aspecto científico e filosófico, define-se como regulações ou regras que orientam algumas práticas pelo conhecimento científico. Por sua vez, para ter validade jurídica, deve conter uma axiomática tendência para a moral e, obviamente, para os fundamentos do Estado, constituído, pelo Direito, na harmonia social, além de sólido embasamento nos costumes. Nesse sentido, a norma torna-se vulnerável de se praticar no Brasil, quando a sua expressão foge dos interesses sociais que a deve fundamentar e da lógica dos princípios que lhe deram lastro.

\section{A história do movimento de normatização da contabilidade americana em divisão}

As perspectivas diversas que a história da contabilidade comprova apontam os Estados Unidos como país proeminente para o desenvolvimento regulador da contabilidade e para a padronização dos balanços, por motivos até econômicos. Em 1833, com a falência do Banco dos Estados Unidos (Silva, 2007; Levene, 1954), firma-se a necessidade de uma padronização contábil americana que pudesse reter as fraudes, visto que o Banco falira por ações fraudulentas e crimes administrativos, o que fez com que as contas e as ações ou operações de créditos fossem representativas apenas no papel, sem uma realidade palpável, definida pelo ajuste de contas ilícito.

O primeiro motivo para uma padronização era coibir fraudes; o segundo, era conseguir informações que pudessem, com fidedignidade, revelar o valor ou aquilo que se passa nas empresas, sem dissimulações - que não deixam de ser mentiras. 
O mercado bancário ou financeiro, segundo Myer (1972), foi o primogênito na emissão das normas, e não foi o mercado de capitais, como muitos poderiam crer.

A divisão do movimento normativo pode ser definida, segundo o nosso ponto de vista, em quatro períodos:

1. de 1895 até 1919 - com a criação de grupos de regulação do mercado financeiro e a crítica acadêmica;

2. de 1919 até 1934 - um período de transição que foi conivente com a Grande Depressão até a criação do Security Exchange Commission (SEC - Comissão de Seguros Mobiliários) e mais grupos de específicos de normatização;

3. de 1934 até 1973 - da emissão dos grupos diversos até a criação do grupo internacional de normas na Inglaterra e do Financial Accounting Standard Board (FASB - Grupo de Normas de Contabilidade), entre outros, e o crescimento do interesse na pesquisa do mercado de valores mobiliários;

4. de 1973 até 2003 - igualmente, pouco depois da criação do International Accounting Standard Committee (IASC - Comitê Internacional de Normas de Contabilidade) e da relevância da normatização de 2003 em diante.

Primeiramente, houve uma grande produção de normas e de grupos para a emissão destas nos Estados Unidos. De maneira geral, não houve movimento semelhante no mundo; no entanto, pelo fato de existirem os mesmos princípios, não quer dizer que eles estejam ladeados de sólidos fundamentos ou que o processo tenha ficado isento de críticas, como todo e qualquer processo praticado pelas mãos humanas - mas isso é outro problema que não iremos aprofundar aqui. 
Houve, durante a história da contabilidade no mundo, uma dezena de contratempos e de fatos, contudo não podemos dizer que isso faz a contabilidade americana superior às demais (cada qual tem o seu valor e sua colaboração para a prosperidade social). Veremos, dentro da bibliografia e da história, qual era o comportamento da regulação, dos institutos e de sua possível influência internacional.

\section{As normas do mercado financeiro}

O professor Myer (1972) conta, com grandes detalhes, como foi o início da normatização americana e as principais medidas adotadas.

Primeiramente, a cautela adotada por parte dos bancos para que não houvesse fraudes nem a falência das instituições levou à criação da Associação dos Banqueiros do Estado de Nova York, ainda no século XIX. Essa associação tinha o interesse de emitir regras para facilitar o crédito, visto que isso era o problema principal dos bancos que faliam, pois cediam o capital de funcionamento para que se pudesse fazer os empréstimos em detrimento do pagamento dos depositantes, o que comprometia a sua liquidez. $\mathrm{O}$ ideal seria ceder dinheiro, que é o estoque do banco, sem comprometer as operações de crédito (Silva, 2008).

O que acontecia com determinada frequência era a concessão de dinheiro sem provas informativas de que a empresa pudesse pagá-lo, embora tais provas pudessem ser encontradas facilmente nos livros de contabilidade e nos balanços.

Portanto, a primeira regra obrigava os banqueiros a solicitarem os balanços; essa norma foi editada em 9 de fevereiro de 1895, quando o conselho executivo da associação decidiu se precaver para proteger as empresas de tal setor.

Depois disso, James G. Cannon, vice-presidente do Quarto Banco de Nova York, dizia que as informações contábeis eram fundamentais para 
atestar a capacidade financeira da empresa e imputavam o critério para ceder os empréstimos ao grau de liquidez da empresa. Ele já projetava uma espécie de formulário de bens de ativo como declaração e uma base para a análise (Myer, 1972).

Em 1900, foi emitida a primeira circular com o formulário-padrão para os concedentes de créditos, fornecida pela mesma associação de banqueiros.

Logo, com lugares para os balanços e sua comparação, tal formulário normativo evoluiu em 1906, e foi aconselhado até por Cannon, com a argumentação de que as demonstrações deveriam ser analisadas pelos gerentes de crédito.

Em 1908, William Rosendale promulgava a ideia de que as empresas, para terem liquidez aceitável para conseguir o crédito, deveriam ter um resultado de $\$ 2,5$ para cada $\$ 1,00$ de dívida, e os gerentes de crédito consagraram tal suposição.

Entre 1905 e 1911, foram publicadas obras que favoreciam a análise do crédito e do investimento financeiro, como base para as práticas bancárias, e adotadas como normas pelas instituições que aconselhavam seguir alguns padrões, com referência, principalmente, à necessidade do uso do balanço em suas companhias (Masi, 1945).

Os processos de análise evoluíram a partir de 1911, e novas instituições ligadas a reservas federais, para o controle e domínio do mercado financeiro, passaram a surgir, até como reguladoras ou emissoras de normas específicas de contabilidade.

Houve algumas contestações ao critério usado para regular os créditos pelo índice de liquidez padronizado e normativo em 1913. A crítica mais contundente foi realizada pelo autor Snyder, o qual apontava outras condições - como a proporção do negócio e o mercado - como fundamentais para a garantia do dinheiro (Myer, 1972, pp. 28-29). 
Em 1914, o Sistema de Reservas Federais regula o uso das demonstrações contábeis, por meio de atos denominados "Atos das Reservas Federais", aconselhando que os bancos associados pudessem redescontar títulos.

Foi criado, então, em 1916, o Instituto Americano de Contadores, denominado "Accounting Institute American" (AIA), para regular assuntos de contabilidade, de forma direta ou por meio de um comitê (Sá, 2003).

Em 1918, quatro anos depois de sua criação, o Grupo de Reservas Federais emitiu uma norma para a padronização de balanços denominada "Métodos aprovados de preparação de declarações de balanço", não somente com as normas para elaborar o demonstrativo, mas também com os procedimentos de auditoria, os princípios e a qualidade da estrutura contábil do documento. Dez anos mais tarde, enviou-se o mesmo documento para o American Institute Certified Public Accounting (AICPA - Instituto Americano de Contadores Públicos Certificados), órgão de especialidade contábil do país e de técnica em nossa disciplina ou profissão (Iudícibus, 2000).

Em 1919, o professor Alexander Wall - o primeiro a produzir um ensaio de análise de balanços em 1905 - critica as posições normativas até publicadas por profissionais que regulavam os padrões de balanços, pois essas normas, ainda que com posições embasadas em alguns dos seus trabalhos, não assumiam uma amplitude de consideração, o que faz apelar para uma relatividade dos estudos.

Portanto, o padrão estático do "dois para um" (para cada $\$ 1,00$ de dívida, a empresa deverá ter no mínimo $\$ 2,00$ ) era contestado cientificamente, pois as normas o acolhiam; todavia, muitas empresas tinham condições para que se pudesse considerar tal resultado como normal.

É importante notar que, até então, os interesses normativos e de aconselhamento de grupos eram levados à tona, mesmo em plenos rudimentos, sobre aspectos empresariais ou contábeis, de dose acadêmica, ou seja, assumiam-se resoluções das instituições, mesmo antes de os cientistas atestarem 
a veracidade ou fortaleza das aludidas questões, o que nos fornece uma primeira etapa de avaliação da história do movimento no país americano.

\section{O pós-1919 e a continuação da normatização, a Grande Crise de 1929 e a evolução das normas no país}

Na primeira fase de normatização (1895-1919), os atos considerados normativos, aqueles emitidos pelos Sistema de Reservas Federais ou pelo Grupo de Reservas Federais, sobre demonstrações, contas e princípios, culminaram, em 1918, num panfleto denominado "Métodos aprovados de preparação de declaração de balanços".

O uso dos balanços tinha o fim de análise. No entanto, esse processo tecnológico da contabilidade necessitava de uma relatividade científica e de fundamentos sólidos de conhecimentos - que ainda não havia, pois se encontrava em fase embrionária -, o que consistiu na base da crítica acadêmica de Alexander Wall em 1919.

O imediatismo em tornar as coisas práticas e a necessidade de uso dessas atividades nas operações financeiras fizeram os grupos emitirem as primeiras regras, sem uma posição acadêmica forte.

Embora não possamos identificar a autoria do panfleto, em 1929, ele foi enviado ao AICPA, o qual procedeu a três edições com base no mesmo documento e, ainda, procurou consolidar melhor os conceitos da técnica contábil até então destacados.

Myer (1972) nos conta que um grupo de terminologia no AICPA fez um relatório preliminar em 1931. Contudo, não sabemos se foi o Accounting Principles Board (АРв - Grupo de Princípios de Contabilidade) ou outro criado com tais intenções (Silva, 2009). 
Surgiram várias obras sobre a contabilidade naquele tempo, na sua parte informativa e analítica, a se destacar a obra de Bliss editada em 1923, denominada "Financial and Operating Ratios in Management" (Informando e operando quocientes em Administração), que apresenta diversos padrões de comportamento numérico das empresas; em 1924, a de Gilman, denominada "Principles of Accounting" (Princípios de Contabilidade), com grandes colaborações ao processo de definição de nossa disciplina no país norte-americano (Masi, 1945).

Tudo leva a crer que a parte experimental da escolha dos dados de análise estava evoluindo para o processo de conhecimento dos consultores patrimoniais. Ao passo que a definição de princípios da parte de Litleton, Patton, Kester e outros também começava a se desenvolver e a criar um tom mais apurado dentro da contabilidade (Silva, 2007).

Com relação à normatização e aos grupos, foi criado o comitê de cooperação com os banqueiros que trabalhavam junto com a empresa Roberto Morris Associates (um escritório para serviços no mercado financeiro) na tentativa de uniformar as instituições bancárias, seus interesses e a profissão contábil. Esse comitê de cooperação trabalhou junto com o comitê de lista de ações da Bolsa, na intenção de providenciar as possibilidades de padronização da estrutura das demonstrações, de modo que elas pudessem dar informações satisfatórias aos investidores de tal mercado.

Aqui, os grupos de emanação de normas começam a sair do foco no mercado financeiro para o mercado de ações, com a parceria firmada entre os institutos que operavam nesse mercado, para uniformizar as informações contábeis. É como se houvesse uma derivação contínua da necessidade de se informar adequadamente na Bolsa, com a proveniência das informações do mercado financeiro.

Myer (1972) nos conta como se demonstrava o uso das informações contábeis naquele tempo: 
Apesar de que nos meados de 1920 já se tivesse feito muito progresso no desenvolvimento de melhores declarações financeiras, tornou-se evidente, para os investidores, que de nenhuma valia seriam os aprimoramentos da técnica contábil enquanto as grandes empresas continuassem a obscurecer intencionalmente as informações de suas declarações publicadas. As empresas argumentavam que esta era uma política necessária para ocultar dos concorrentes os dados vitais sobre a empresa. Para o investidor, entretanto, parecia justo que ele tivesse dados corretos a respeito de uma empresa na qual ele tinha investido ou pretendia investir o seu dinheiro. (p. 31)

Mesmo com os grupos formados nas parcerias dos institutos bancários e contábeis, junto com os demais do mercado de capitais, ainda havia práticas obscuras que influenciavam a fidedignidade das informações, como nos conta o mestre acima citado.

Em 1926, Ripley, em publicação polêmica, denunciou a tática de empresa grandes em manipular informações moldadas para os acionistas; 0 autor, com uma riqueza de detalhes, apontava as principais manobras, com citação até de empreendimentos importantes. No mesmo ano, a Bolsa de Valores de Nova York (Nyse) passou a exigir relatórios contábeis fundamentais sem 0 parecer da auditoria (Hendriksen e van Breda, 1999). Tais acontecimentos viriam a produzir uma instituição disposta a fiscalizar tal mercado e tais práticas, que era a SEC depois da Grande Depressão.

Em 1929, houve a Grande Depressão e a crise mundial, causadas igualmente pelas demonstrações mentirosas dos balanços e pelas ações fraudulentas, além do excesso de produção econômica pronto a escoar. Nessa época, surgiu o conceito de "princípios geralmente aceitos" por parte do AICPA (Franco, 1988).

O dinheiro que se achava no papel sem materialidade suficiente foi um dos fatores da crise, fazendo o pulmão econômico do mundo parar de respirar por um instante, num colapso ou distúrbio que influenciou a queda da economia mundial. Em realidade, o papel que representava os valores existia sem uma riqueza real; contas e ações sem valor palpável, 
sem controle e fiscalização no mercado pertinente. Nesse contexto, a falta de padronização dos balanços e das contas foi a primeira justificativa de normatização oficial, embora a Comissão de Segurança dos Títulos tivesse sido criada para fiscalizar e promover a regulação.

Sabia-se que, "à época, as empresas foram duramente criticadas pelo papel que se julga terem desempenhado" e que a culpa estava "no fato de que os próprios contadores ainda não foram capazes de estabelecer algumas regras padronizadas" (Hendriksen e van Breda, 1999, pp. 57-58), apesar de já existirem institutos com tal finalidade.

Nesse período, Hoxsey, assistente do comitê de empresas registradas na Nyse, denominado "New York Stock Exchange" (Central de Corretagem de Estoque de Ações de Nova York), precisou de amparo de auditores, sendo George May, pertencente à Price Waterhouse 3 , um dos primeiros a lhe oferecer tal assessoria, que foi concretizada em 1930 (um ano depois da Grande Depressão).

Depois, May se desliga da Price Waterhouse e cria um próprio escritório para si, especializado na área de auditoria, fazendo um acordo entre o AIA e a New York Stock Exchange sobre a direção de Hoxsey. Então, após a crise, ele fica encarregado de guiar uma comissão de pronunciamentos contábeis: o Committee on Accounting Procedures (CPA - Comitê de Pronunciamentos Contábeis), criado pelo AIA.

Em 1931, foi feita a lei que criou a SEc para substituir a Federal Trade Commission (Comissão de Comércio Federal), o que tornou o terreno para a atuação de outros grupos mais fértil. Em 1933, passa a existir a obrigatoriedade de balanços auditados e, em 1934, a SEC passa a atuar.

O crescimento dos grupos de regulação e o estabelecimento das normas interessavam principalmente ao mercado de capitais, juntamente com a

3 Literalmente, traduzido como "Casa do preço da água". É uma das cinco grandes empresas multinacionais de auditoria que atuou no século xx. 
presença das grandes empresas de auditoria, porque, para haver negociações em bolsa, eram necessários os pareceres de auditores.

Em 1932, o próprio AICPA, em um trabalho denominado "Professional Standards" (Normas profissionais), comentava que tinha feito recomendações à Nyse, o que viria a ser praticado em 1934 e culminado num programa de pesquisa denominado "Accounting Research Bulletins" (Boletins de pesquisa contábil), publicado por comitês sob sua responsabilidade (que seriam dois básicos: o de princípios e o de pesquisa contábil).

No mesmo ano de início da atuação da SEC, houve uma lei de comércio de títulos que exigia padrões ou uma estrutura específica para os relatórios contábeis. Assim, obrigava as empresas que tivessem títulos na bolsa a seguirem uma estrutura para os seus demonstrativos.

A mesma Comissão de Títulos e Bolsa - que trabalhou junto com a Robert Morris Associates e com a comissão dos banqueiros - preconizou a obediência de algumas normas para se adequar à exigência da lei.

Myer (1972) reproduz o primeiro relatório da comissão, nos seguintes trechos:

A comissão não julga a solidez de um título. A diretriz básica é informar ao investidor os fatos relativos aos títulos a serem oferecidos à venda no comércio interestadual e internacional e sua meta é colocar frente ao investidor informações verdadeiras. (p. 32)

Mesmo a comissão dizendo que não se deve julgar um título - muito embora lhe interessassem informações verdadeiras -, há algum sintoma contraditório, com neutralidade que ousa transparecer.

Se o escopo é atingir informações verdadeiras, a qualidade destas deve ser prerrogativa básica; portanto, a sua solidez é parte dessa qualificação. Assim, não existe informação verdadeira sem qualidade e, obviamente, sem o julgamento da referida. 
Um ano depois da criação da SEC, passaram a existir novos grupos profissionais e institutos que se imputavam como elaboradores de princípios. Havia, antes, o aviso do perigo em manter informações não fidedignas, por isso a necessidade da criação de grupos para regular o mercado com as normas.

Nesse processo, passou a haver uma interferência para o estudo do mercado de capitais. As ações eram negociadas em bolsa, e os balanços e as contas - informes de nossa disciplina - eram utilizados largamente para o processo de negociação de ações.

Logo, na década de 1950, culminou-se a tendência positiva na economia, que foi absorvida até pelos grupos que diziam ter sumo interesse na "informação do mercado de capitais", embora isso fosse objeto da economia, e não da contabilidade.

No mesmo ano que Friedman publicava The Methodology of Economics Positive (A metodologia da economia positiva), houve uma tentativa de voltar a prática contábil e sua vertente ligada ao mercado de capitais para a ciência da Economia (Bilas, 1976). Contudo, Watts e Zimmerman, no final da década de 1980, apropriaram-se disso para a contabilidade, com uma ausência de lógica entre a metodologia e o positivismo contábil (Silva, 2009, p. 221).

O estudo econômico voltado para o mercado de capitais e o interesse dos grupos normativos em regular esse mercado, do qual os balanços eram peças fundamentais, criaram uma cópia da metodologia econômica para a contabilidade como se esta fosse doutrina. 


\section{Um período de transição dos grupos e dos produtos normativos, de 1935 a 1973}

No terceiro período da história da normatização americana, cresce o número de grupos e de suas respectivas emissões sobre as normas de contabilidade.

Ora em vez, existiram boletins, conteúdos, panfletos de basicamente três grupos, como veremos com mais detalhes. Houve uma tendência para a contabilidade como informação, devido à política de regulação dos órgãos, atrelada ao mercado de capitais, pois a Bolsa era o principal meio de negociação e crescimento das empresas americanas. O mercado de capitais, como usa constantemente a informação contábil, passou a ser o campo mais observado de entendimento da "informação contábil".

Nesse intervalo, a conceituação, até dogmática, de "contabilidade como sistema de informação" ou com sua prática restrita às informações para os usuários se tornou popular e entrou em voga, até porque não havia outro interesse, senão o de normatizar e de prescrever como deveria ser a informação contábil e o que ela deveria relatar.

Em 1935, por uma transformação da Associação Americana de Professores de Contabilidade, surgia a American Accounting Association (AAA - Associação dos Contadores Americanos), a qual tinha interesse de produzir princípios. Em 1936, havia publicado um trabalho denominado "Um pronunciamento experimental de princípios em que se baseiam as demonstrações contábeis das empresas" (Franco, 1988). Essa mesma instituição passou a produzir princípios de 1936 a 1965, depois culminando na Accounting Review (Revista de Contabilidade), com singular aceitação.

Da parte do AICPA, a comissão era o APB e o Accounting Research Board (ARB - Comitê de Pesquisas Contábeis), ambos produziam boletins ora de regras de contabilidade, ora de pesquisas contábeis. 
De 1939 até 1953, o APB publicou os Accounting Research Bulletins (Boletins de pesquisa contábil). Havia também, desse grupo, os АРВ Statements (Declarações do APB) e os Accounting Research Study (Estudos de pesquisa contábil), com base no trabalho do escritor Maurice Moonitz, que serviu de alicerce para muitas obras de contabilidade (Iudícibus, 2000).

Da parte do CPA, sob a liderança de George May, foram emitidos, de 1936 até 1959, cerca de 50 boletins de pesquisa contábil (com o mesmo nome da outra comissão) e, ainda, quatro trabalhos de terminologia (Accounting Terminology Bulletins - Boletins de terminologia contábil).

Existiu, portanto, uma forte influência do AICPA com o APB e o ARB a partir de 1939, com os boletins de pesquisa contábil, e do AIA com o CPA a partir de 1936, que publicaram os mesmos documentos normativos até a década de 1950 (Paulo, 2002).

Hoxsey, presidente da organização que lidava com os títulos listados na Nyse, porém, pressionou o AIA para regras mais rigorosas, o qual, sob a presidência de May, passava a emiti-las. Exemplos dessas regras eram que 0 lucro não deveria ser reconhecido antes da venda; que as despesas deveriam ser lançadas na demonstração de resultado; que os lucros de uma empresa antes de ela ser comprada seriam dela e que os dividendos representavam dívidas (Hendriksen e van Breda, 1999).

Naquela época, esse tom de normatização era considerado insignificante por parte de inúmeros profissionais, membros do AICPA, como Byrne, que argumentavam que as normas deveriam ser obedientes a princípios, os quais são verdades fundamentais.

Os próprios Hendriksen e van Breda (1999) contam que May, em realidade, defendia uma liberdade às próprias empresas, e que estas poderiam decidir em matéria de contabilidade, mesmo sendo ele presidente de uma das mais importantes comissões de normas. May falava em tom estranho e, por mais incrível que possa parecer, o AICPA adotou as suas definições editadas antes da década de 1940 - fato esse surpreendente. 
Na mesma ocasião, Paton e Litleton publicam uma obra denominada "An Introduction to Corporate Accounting Standards" (Uma introdução para a corporação de normas contábeis), como se fosse um manifesto.

A liderança de May durou até 1953, no mesmo período que o APB parou de emitir boletins normativos. Sua substituição por James Dohr levou à emissão de boletins de 1955 a 1957 voltados às práticas de contabilidade e à regulação do mercado de capitais, que em muito influenciou a SEC (Sá, 2003).

O AAA tentou reformular princípios nesse ínterim, com o objetivo de fazer com que eles fossem adaptados a normas ou convenções em 1957.

Foi produzido o AICPA Special Committee Program (Programa do Comitê Especial do AICPA), com o interesse de produzir uma estrutura de princípios para a informação contábil de modo mais organizado, com a publicação do Estudos de pesquisa de contabilidade (que já nos referimos), com base em dois autores: Maurice Moonitz e Robert Sprouse.

Em 1959, o AICPA promoveu uma estrutura básica sobre os princípios de contabilidade "geralmente aceitos", nos quais havia quatro tipos de quesitos: 1. postulados básicos; 2. princípios gerais; 3 . fixação de regras para a aplicação de princípios; 4. realização de pesquisas permanentes sobre estes (Franco, 1988). Mais tarde, houve uma reorganização desse instituto com o fim de estabelecer os princípios gerais - embora fossem emitidas diversas normas sobre eles.

Um estudo interessante em 1961, de Pauls Grady, o Handbook of Modern Accounting (Cadernos da Contabilidade moderna), apontava uma interpretação das elaborações do AICPA dos seus boletins de pesquisa contábil. Nesse documento, Grady dizia que as regras do AICPA e de seus comitês regulavam apenas a escrituração dos fatos, como podemos traduzir alguns: 
Objetivo A - Contabilizar vendas, recebimentos, receitas, custos de vendas, despesas, ganhos e perdas [...]

Princípio A-1 - Vendas e receitas não devem ser antecipadas ou sobre ou subavaliados de forma relevante $[. .$.

Princípio B-1 - Quando houver duas ou mais classes de ações, contabilizar o capital investido em cada tipo e revelar os direitos e preferências nos dividendos $[\ldots]$

Objetivo c - Contabilizar os ativos investidos na empresa pelos acionistas [...]

Princípio c-1 - Itens classificados como ativos circulantes não devem ser mantidos a valores superiores em que razoavelmente possam ser realizados dentro do ciclo operacional normal da atividade em particular [...] (Franco, 1988, p. 286)

Embora fossem aceitas por todos esses argumentos como iguais a princípios, podemos dizer que são apenas regras de práticas rotineiras. Por exemplo, contabilizar vendas ou determinar o valor da conta não é o princípio, é uma prática comum; o princípio da mensuração do valor e do reconhecimento da competência sim formam princípios gerais dessas atividades lastreadas em classificação e conceitos.

Esse texto foi aceito por todos como fundamental para a prática, porém existem itens que impregnam alguma ausência de definição clara ou, ainda, misturam conceitos (no caso do princípio A-1, encontra-se "contabilizar 'vendas' e 'receitas"' e seria melhor dizer "receita" somente, porque este é o fenômeno geral, sem diferenciação do tipo, que é a "venda", até porque dá para entender a diferença dos dois fatos).

Grady aceitou esses termos do AICPA. Embora argumentasse que eram restritos à contabilização, sem serem princípios, recomendava a sua aplicação quando pregava que os princípios deveriam ser: 
1. Práticas comumente encontradas em negócios.

2. As exigências e pontos-de-vista das Bolsas de Valores, como líderes na comunidade financeira.

3. Os sistemas uniformes de contas e regras contábeis das comissões reguladoras.

4. Os regulamentos e opiniões contábeis da SEC [...]

5. Opiniões publicadas pelas comissões do AICPA [...] (Franco, 1988, p. 285)

Portanto, mesmo reconhecendo que os boletins emitidos pelas comissões do AICPA não eram princípios, referia que, para reconhecê-los, deveria existir a emanação do mesmo grupo, ou seja, é como se disséssemos que não deveríamos seguir a lei, mas sim o Estado, o que gera uma dicotomia evidente, já que quem faz a lei é o Estado.

Em 1969, publicou-se o CPA Handbook (Cadernos do CPA), que continha os princípios que deveriam ser encarados segundo vários pontos de vista e poderiam ser considerados como "regras do comportamento humano, adotadas pelo homem" (Franco, 1988, p. 290).

Depois, no mesmo caderno, falava-se dos pressupostos básicos, entendidos como o que se supõe antecipadamente:

A empresa considerada como uma unidade contábil, é independente de seus proprietários.

A continuidade da empresa como unidade.

As variações do poder aquisitivo da unidade monetária não são importantes.

As operações podem dividir-se em períodos contábeis para fins de informação e alocação de suas receitas e seus gastos.

A política contábil deve ser conservadora.

A contabilidade deve basear-se no custo. (Franco, 1988, p. 290) 
Todavia, aqui já era apontada a noção da evidência do custo histórico e da uniformidade, além da refutação das variações do poder aquisitivo como fundamentais para a informação contábil, sendo que estas últimas, quando jogadas no balanço, poderiam deturpá-lo. Isso porque as variações são importantes, mas não podem ser colocados índices fictícios em contas na tentativa de atualizar o valor.

Embora houvesse um ar de princípios nos argumentos desse caderno, ele era concebido como pressuposto, ou seja, sem uma "firme certeza". Alguns desses pressupostos são, em realidade, bases fundamentais; outros, devido à maneira pela qual são expostos, impregnam uma dificuldade de interpretação: por exemplo, como entender "a continuidade" como "unidade", já que aquela é, em verdade, uma fenomenologia, um conceito fundamental, portanto não "unidade".

Na década de 1960, foi produzido um sistema de princípios e convenções com base em diversos autores também acadêmicos como Finney, Miller, Mattesich, Chambers, Goldberg, Anthony, com uma estrutura semelhante à apresentada hoje no Brasil nos cursos de teoria da contabilidade (Iudícibus, 2000). Ao mesmo tempo, o AICPA tentava manter um nível regular de emissão desses princípios e de normas ou boletins de regulação, com alguns trechos semelhantes. Assim, esse instituto era um dos mais responsáveis pela emissão de normas, apesar dos demais — AAA e AIA —, até 1973, com a criação do FASB, o qual publicou os boletins com escrita símile.

\section{O quarto período da história da normatização americana e a presença de grupos internacionais de normatização}

O ano de 1972 foi marcante para a história geral da normatização com embasamento americano. Nessa data, mais de 80 países criaram o IASC, no âmbito do X Congresso Internacional de Contadores, com influência, ainda hoje, na regulação de muitos países. 
Um ano depois, surge o FASB. Nesse contexto, os comitês do AICPA passaram a ser responsabilidade do FASB, que usava os boletins para uma revisão do seu conteúdo.

O AICPA procurou igualmente reformular 42 boletins seus e publicou uma série de documentos normativos denominados "opiniões", "pronunciamentos" e "interpretações contábeis". No entanto, é nítido verificar que "muitos boletins publicados foram anteriormente alterados, substituídos ou cancelados, à medida que as condições afetavam a sua utilidade" (Franco, 1988, p. 294). Ainda, como muitos dos boletins dos grupos mencionados eram atestados como opiniões ou pressupostos, no caráter de "básicos", sua validade era questionada, e seu conteúdo era sujeito às mudanças diversas devido à debilidade dos seus fundamentos, já que não contavam com a imutabilidade ou a constância no tempo como os princípios científicos, considerados verdades fundamentais ou macrorregulações.

Enfatiza-se que, se houvesse uma qualidade aceitável em tais regras, não haveria a "troca" ou a "alteração substitutiva" dos mesmos documentos, pois não se pode ter coisa verdadeira e sólida que se altere a toda hora, ainda em nível de conceito elementar. Se aconteceram essas alterações constantes, é porque o conteúdo era contestável na prática e na teoria, ou melhor, na ciência, exigindo permutações frequentes, tal como um escritor que se gaba por escrever algo certo, mas, em realidade, registra as letras erradamente; logo, deve alterar constantemente o seu texto. Portanto, houve tentativa de melhoramento; por isso, pouco depois da criação do grupo internacional, criou-se o FASB.

A APB do AICPA, em realidade, foi substituída pela FASB, que gozava de um prestígio incomum, sendo o mais importante órgão de regulação dos Estados Unidos e com mais autoridade naquela época que o próprio IASC.

Já em 1975, o AICPA publicava um estudo intitulado "Professional Accounting in 30 Countries" (A profissão contábil em 30 países), cuja primeira edição era de 1964, com apenas 25 países; apresentava conteúdo semelhante ao do IAsc. 
O FASB começava a produzir uma série de conceitos de contabilidade, numa proposta de modernização dos anteriores boletins emitidos pelo APB e pelo AICPA. Nesses novos documentos normativos, existe a indicação de características da informação contábil, entre outras definições mais. Logo, há uma supremacia desse instituto nas normas de contabilidade, no país americano, com poucas discordâncias em termos básicos com o IASC, todavia com uma semelhança verossímil na estrutura, com a diferença especial de ser uma organização mantida pelo governo.

Ao mesmo tempo que a normatização tinha chegado a topos mundiais, com nítidos exemplos da luta americana e dos diversos fenômenos de regulação evidentes em sua história, a Organização das Nações Unidas (ONU) procurava manter uma cadeira referente às normatizações de empresas. A comissão de informação que a onU utilizava para entender e promover regulações sobre as normas contábeis, também com relevância internacional, é hoje conhecida como "International Standards Accounting Report" (ISAR - Audiência ou Relatório Internacional de Normas de Contabilidade) e constituía uma cadeira relacionada às empresas, por ser o estudo dessas células econômicas motivo de direito social (Franco, 1999).

Havia uma comissão brasileira representada por Antonio Lopes de Sá, em meados da década de 1970, o qual, na primeira posição discursiva, discordou dos 39 itens das então normas emanadas pelo instituto, com todas as fundamentações em doutrina, o que levou à sua consagração. Por motivos diversos, o mestre mineiro deixava a comissão para então ser substituído pelo professor Hamilton Parma, que produziu colaborações, discordâncias, posições e interpretações que eram publicadas em relato de audiência, em pequenos cadernos denominados "Blue Books" (Livros azuis), em vários fascículos, alguns destes disponíveis na biblioteca do Conselho Regional de Contabilidade de Minas Gerais (CRCMG).

Essa instituição da oNU era composta de 36 membros, com representações por continentes e países, e com trocas aferidas por sorteio, além de os aludidos pertencerem a inúmeras academias e escolas de contabilidade. No início da década de 1980, o grupo foi reduzido a menos de 20 pessoas. 
Primeiramente, as reuniões aconteciam na Inglaterra, depois, numa sede da ONU em Nova York; quem representava o país tinha o visto da embaixada e era custeado em suas despesas pelo departamento fazendário (de uma forma excêntrica, mas o era).

As reuniões (segundo os próprios relatos do professor Parma feitos a nós diretamente em conversa pessoal) tinham uma organização invejável e com um curso de horas laboriosas. Nelas, discutiam-se os temas de contabilidade para a regulação e a normatização, todos com direito a voto; eram realizados discursos, registros de concordância ou discordância e relatos, em formas de pareceres assinados pelos participantes. As reuniões eram democráticas, e a presença da academia, evidente, o que fez com que se tivesse um prol mais efetivo em torno de "verdadeiras" normas de contabilidade. Contudo, houve, aos poucos, a retirada dos acadêmicos da escola tradicional, da europeia e da latina, para se manterem apenas acadêmicos adeptos ao sistema anglo-saxônico.

Mesmo com a criação do grupo internacional IASC, do órgão da ONU e do FASB, inúmeras fraudes aconteceram em meados da década de 1970. Entre 1974 e 1978, devido a essa situação, houve uma manifestação em todo o país norte-americano.

No ínterim dos escândalos, o FASB tentava manter a sua missão, mas quase sem efeitos; a SEC se mostrava muito tímida nesse sentido, e as empresas fortes, por sua vez, fechavam e demonstravam a sua fraqueza com contas podres, o que, no início, fez o Ministério Público e o Senado do país tomarem providências. Houve, portanto, uma comissão parlamentar de inquérito para apurar os acontecidos de maneira analítica e profunda.

O senador Lee Matcaff foi a cabeça dessa comissão parlamentar de inquérito, que deu origem à obra The Stablishment Accounting ( $O$ conluio contábil), a qual tratava da descoberta e denúncia de um acordo entre as grandes empresas de auditoria, dos grupos de normatização e dos monopólios, para emitirem regras ou manterem uma contabilidade que se fizesse ao múnus de "porcaria" (como concluía o inquérito). 
Havia enormes celeumas no uso da contabilidade e forte alargamento para uma prática empírica sem convicções adequadas ou sem princípios científicos. Segundo o documento da comissão, tal condição política era pressionada pelas multinacionais de auditoria, as quais recebiam forte pressão dos grupos (Sá, 2003; Parma, 2002).

Ou seja, as próprias entidades reguladoras, com a finalidade de emitirem as normas que pudessem reger a prática contábil, pertenciam ao acordo ilícito e prejudicial, que fomentava uma enorme máfia que envolvia as multinacionais de auditoria e as grandes empresas, com acordos milionários, para manipular regras que pudessem beneficiar os balanços, com a criação da expressão "windows dressing" ("janelas enfeitadas"). Isso fez com que a base da escola americana nesses grupos fosse até denominada de "fortuita" ou "acidental", devido a esses efeitos (Parma, 2002).

Graças à intervenção do professor Parma, alguns exemplares foram remetidos ao Brasil: um dos exemplares tinha sido destinado ao professor Sá (que somente participou da primeira reunião e foi substituído por Parma); um se encontra na biblioteca do CRCMG; outros ficaram para a Receita Federal e outros foram distribuídos como presente.

Após essa comissão ter concluído e com o intuito de avançar no campo da pesquisa, houve esforços de acadêmicos na crítica, como o professor Stephen Zeff, sobre a qualidade das normas, e o professor Abraham Brillof, com uma obra denominada "More Debits than Credits" (Mais débitos que créditos), na ironia do uso da contabilidade em seu país. Por sua vez, o Senado não prosseguiu suas pesquisas pelo falecimento do presidente $-\mathrm{e}$ seu autor - da comissão.

De todos os modos, entendemos que o esforço para uma normatização internacional palpável passa a surgir por essa comissão da onU e pela criação do grupo internacional, com a influência americana. $\mathrm{O}$ reflexo de tal grupo era um efeito do então IASC e do International Accounting Standards Board (IASB - Grupo Internacional de Normas Contábeis), no entanto o processo passou a ser consolidado por somente 14 pessoas no 
grupo internacional. Ao menos, parecia haver essa distinção com respeito aos acadêmicos tradicionais e da doutrina europeia e latina, embora hoje isso não possa se afirmar.

O FASB, mesmo sendo um dos institutos mais respeitados do mundo, também cede influência ao IASC, que se tornou um trust (monopólio), do qual fazem parte o IASB, com 14 membros (entre eles, em 2008, entra Pedro Malan) e o International Financial Reporting Interpretation Committee (IFRIC - Comitê Internacional de Interpretação e Relatos de Contabilidade), principalmente (Silva, 2009).

Ambos elaboram as normas Internacionais de Contabilidade (NIC) e as International Financial Reporting Standards (IFRS - Normas e Relatórios Internacionais de Contabilidade), que hoje influenciam todo o mundo.

Com isso, finaliza-se um dos capítulos da história da normatização americana, sobre a qual já apontamos alguma relação com o movimento internacional.

\section{O período de normatização internacional e a relação com o movimento americano}

Com a criação do FASB em 1973, o CPA é substituído; portanto, o AICPA deixa de ter uma relação direta com a normatização americana. Podemos dizer, no entanto, que o antigo CPA, o FASB e o AICPA, junto com os demais grupos, teriam que acolher exposições feitas pelo IASC a partir de 1972, já que este fazia o jus de grupo internacional.

Embora exista o nacionalismo supremo dos americanos, o fASB é a autoridade mais confiável para os seguidores das normas de contabilidade; todavia, a influência do comitê internacional se faz prevalecer em alguns momentos. O principal objetivo de regular os princípios de contabilidade e produzir normas no país americano resultou, em forma, no comitê internacional de normas. 
Ao mesmo tempo, a onU tinha uma comissão para tais assuntos, da qual fizeram parte Antonio Lopes de Sá e Hamilton Parma ${ }^{4}$. No IASC, tivemos de início a presença de Pedro Malan, economista que foi ministro da fazenda, mas que, para assumir o cargo, apropriou-se de uma bagagem de contabilidade num curto tempo (Silva, 2009). O mesmo instituto internacional, no começo de sua atividade, admitiu conceitos já expostos pelo FASB, que eram o da entidade e o da continuidade, e os incluiu como postulados de igual nome (Franco, 1988).

Desde a década de 1950, o AICPA percebia que havia divergências nas práticas contábeis adotadas, e isso era nítido nos outros países, como ficou demonstrado em outra série de trabalhos na década de 1970. Por sua vez, o IASC procurava manter a sua missão na década de 1980 com a edição das normas que deveriam ser aplicadas no âmbito mundial. Isso culminou, no início da década, em 24 normas internacionais relacionadas a assuntos diversos, algumas das quais foram reproduzidas por Franco (1988):

1 - Divulgação das políticas contábeis

3 - Demonstrações Financeiras consolidadas

4 - Contabilização da Depreciação

5 - Informações a serem divulgadas nas Demonstrações Financeiras

11 - Contabilização dos Contratos de Construção

12 - Contabilização do Imposto de Renda

15 -_ Informações que refletem os Efeitos das Mudanças de Preços

4 Bem antes, havia um grupo na Europa motivado por acadêmicos na tentativa de padronização internacional, do qual fez parte o mestre mineiro e Alberto Almada Rodrigues; contudo, Sá fizera o primeiro ensaio de padronização em 1953, na sua obra Princípios e Preceitos de Contabilidade Industrial, ao final com um apêndice. 
16 - Contabilização do Ativo Imobilizado

17 - Contabilização dos Arrendamentos (leases)

23 - Capitalização dos Encargos Financeiros. (p. 310)

Entre as regras estabelecidas em 1982, uma interessante sobre o arrendamento tinha uma excêntrica recomendação, a de se colocar os contratos de leasings operacionais como ativo:

44. Os ativos detidos em locações operacionais devem ser reconhecidos como ativo fixo tangível no balanço dos locadores.

45. Numa locação operacional, os riscos e recompensas inerentes à posse de um ativo permanecem com o locador. Por isso, o ativo é tratado pelo locador como um ativo depreciável. (IASB, 2010, s/p, numa primeira versão em 1982)

Na década de 1980 e 1990, vemos muitos registros das fortes influências de grupos com suas emanações, mas a importância para o tratamento dessas normas era quase imperceptível. O número da regra foi conservado e ela é considerada ainda hoje, com poucas reformulações, orientadora das operações dessa natureza.

Começa, no Brasil, mais detidamente na década de 1990 (com as brigas de estabelecimento de inflação nos balanços e seguimento de normas), um movimento literário de abordagem, seja ela de crítica, seja de descrição da natureza dessas normas.

Os adeptos da cultura anglo-saxônica discutiam muito pouco sobre tais assuntos, embora fosse clara a sua tentativa de colocar o padrão americano, absorvido pelo Comitê Internacional, como cânon da contabilidade do Brasil. Nessa tentativa, havia a elaboração dos princípios aos moldes das emanações dos grupos dentro das matérias de teoria da contabilidade, apegando-se ao "utilitarismo" como escudo e refutando, até com radicalismo, 
as demais posições doutrinárias de nosso saber (que não eram normativas, mas, base para as tais).

Essa maneira de pensar a contabilidade, de alguma forma, influenciava o mundo acadêmico brasileiro e é praticada ainda hoje nos institutos universitários de maior celebridade do país, que detêm a maior parte dos investimentos públicos em pesquisa também.

Assim, nos textos da teoria contábil, havia a sobressalente posição normativa voltada aos princípios, na defesa máxima da finalidade da informação da contabilidade, como se fosse a exclusiva em nossa ciência, até com sensível crítica às demais doutrinas latinas e europeias de contabilidade (com um rigor irônico e de taxação). Dessa maneira, na década de 1990, havia já um terreno fértil para tais perspectivas, com a participação da crítica de diversos catedráticos na defesa do sistema anglo-saxônico ou na oposição a ele.

Todavia, com o tempo, em 2002 e 2003, uma onda de fraude ocorreu nos Estados Unidos, com o envolvimento de mais de 25 grandes empresas, algumas, inclusive, dominavam grupos brasileiros. Isso fez com que se repensasse o sistema de normatização adotado no Brasil como modelo até de teoria contábil (embora as normas e princípios fossem "emanações" da teoria, e não o corpo desta). Nesse contexto, a Academia Brasileira de Ciências Contábeis fez um manifesto, pela mão do seu então presidente Antonio Lopes de Sá, no qual isentava a contabilidade científica da sua manipulação especulativa - a causa maior para as fraudes. Além dele, outros acadêmicos faziam inúmeras manifestações sobre o acontecido.

Em 2003, passava a existir, nos Estados Unidos, a Lei Sarbanes-Oxley para punir os crimes contábeis e fiscais por parte do Senado e tentar refrear tal movimento. No mesmo ano, no Brasil, ficava evidente que as considerações da contabilidade deveriam observar a americana e, em especial, a do IASB (Iudícibus, 2003a); além disso, já se pensava em ter um Comitê de

5 A lei leva esse nome devido aos seus dois autores senadores. 
Pronunciamentos Contábeis (CPC) que auxiliasse no processo de padronização (Iudícibus, 2003b).

Em 2004, como ocorreu em outros países, no Brasil, houve a necessidade clara de impor um padrão contábil americano, ligado à estrutura do IASB, com referência à do FASB, até em obras de teoria da Contabilidade. Todavia, com a crise americana, as normas não conseguiram cercear as contas falsas, as manipulações, as dissimulações, as simulações e as fraudes. Portanto, passou-se a se atentar para o processo internacional e para o IASB, cuja abordagem era carente de um vigor maior, por ser extremamente tímida.

Nesse contexto de história americana e no sentido de normatização, o IASB se sobrevalia como uma solução para a questão normativa e, por determinismo, o mesmo grupo comentava que antes não se destacava fortemente, porque estava estudando as práticas de cada nação. Contudo, em 2003, veio estrategicamente se ostentar (embora antes não houvesse alguma menção dessa "estratégia", como saber que, exatamente nesse ano, haveria tais fraudes que cumulassem na busca de uma solução que fosse a panaceia para os problemas regulatórios ou normativos?).

No frenesi regulatório, as normas - pouco mais de 40 - saíam e eram seguidas quase à risca, o que não segurou uma fraude crescente em 2007, final do reflexo de 2003.

Mesmo com as críticas em 2008, os inúmeros seguidores desse movimento pensavam em alcançar reflexos em 2009 para culminar em 2012 com o seguimento de todas as regras, embora mais aplicáveis às sociedades que tivessem negociação com o mercado de capitais, efeito da antiga normatização americana.

Por estas e muitas outras condições, tudo leva a crer que o movimento internacional se embasou em muitos critérios americanos: primeiro, na cópia estrutural de muitos conceitos do FASB; segundo, na maneira de usar as normas e para quem usar; terceiro, nas finalidades acopladas da política americana. 
Prontas a alcançar o ano de 2012, as International Accounting Standards (IAS - Normas de Contabilidade Internacional) ou as NIC são aplicadas em todas as empresas e marcam, relativamente, a história da normatização mundial.

\section{Considerações sobre os problemas emanados neste trabalho e observações sobre as normas}

Ao início de nosso trabalho, apresentamos dois problemas básicos que a história da contabilidade nos auxiliará a responder agora, que nos dedicamos às observações atuais das normas.

O primeiro deles é se a finalidade ética e científica da normatização atingia o seu intento pela história. A resposta para tal pergunta ou problema é, logicamente, "não". Com base nas abordagens feitas, na revisão da literatura e em documentos bibliográficos, não encontramos uma uniformidade ética e científica da normatização, mas sim o apelo de grupos e a necessidade de regular os mercados apressadamente e a quaisquer custos, com movimentos "fechados" de empresas responsáveis pelo aludido movimento político de normas.

Isso é possível de encontrar quando analisamos a primeira fase da normatização, na qual, sem o consenso dos especialistas de contabilidade, já se regulavam padrões para interpretar os títulos e os níveis de liquidez no mercado financeiro.

Depois, com a pressa de querer regular os mercados, as instituições pertinentes faziam contratos com empresas particulares que culminavam em projetos de normas, que não refrearam a Grande Crise de 1929. Nesse intervalo de tempo, desenvolvia-se a tentativa de regular as práticas, e as críticas sobre a forma pela qual se faziam as regras eram periódicas.

Logo, com a presença do AICPA e do AIA, o comitê do CPA era gerenciado por figuras que não entendiam especialmente de contabilidade - como 
na análise dos textos reproduzidos - e normatizavam sobre práticas comuns (por exemplo, o lucro existe depois da venda; o dividendo é dívida; as despesas devem estar na demonstração de resultado; como se isso fosse suficiente para ter o múnus de princípio), mas que eram acolhidas pelos órgãos de classe em nível de "contabilidade moderna" ou "estrutura geral". Também, os próprios grupos especializados na regulação não produziam princípios ao nível de científico, não obstante "regras de contabilização".

Percebe-se, durante o trabalho, que as referências contábeis apontam um terreno híbrido que os mesmos grupos mantinham, com o acordo de empresas particulares e a pressa para se regular o mercado. Se assim não fosse, a afirmação que reproduzimos novamente de que "muitos boletins [aqui ele fala dos documentos normativos expedido pelos grupos para o público contábil] publicados foram anteriormente alterados, substituídos ou cancelados, à medida que as condições afetavam a sua utilidade" (Franco, 1988, p. 294) não seria verossímil. Ora, se alteravam constantemente a panfletagem, é porque não se tinha certeza sobre seu conteúdo; nesse sentido, eram considerados "suposições" ou "pressupostos" com carência doutrinária.

Juntamente com isso, uma finalidade ética não se encontrava com clareza, visto que o interesse era regular os mercados, em especial, o de capitais, e foi isso que politizou a doutrina contábil daquele país, misturando a metodologia da economia positiva com a nossa ciência, refutando a sua autonomia em relação aos outros ramos do saber, em detrimento do seu arcabouço cultural já ostensivo, mas renegado brutalmente.

Como o mercado tem o interesse da informação e das ações de contas, e como a contabilidade tem o grau de controlá-lo pelos balanços, foi reunido todo esse amálgama de prática com o interesse especulativo e impregnado no corpo da pesquisa contábil, desenvolvendo a pesquisa voltada para o mercado de capitais (embora seja este objeto da economia, e não da contabilidade). 
Desde a década de 1930, a mistura das entidades de classe, grupos de normatização, de regulação dos mercados com empresas privadas marcavam interesses também aéticos, que fugiam da responsabilidade atribuída a cada um. Ora, cada grupo tinha o seu interesse e a sua responsabilidade, sendo que a mistura, pelos acordos, que queria absorver a troca de interesses e, igualmente, o controle de mercados feria a ética impugnada a cada um.

Já pensou se as entidades da medicina se misturassem com as empresas farmacêuticas e de enfermagem para produzir acordos sobre objetos, instrumentos e elementos da saúde? Logicamente, grande quizila existiria.

Com as diversas alterações dos panfletos normativos e com a presença do FASB, não houve proficiência para segurar as crises e as fraudes ocorridas na década de 1970, ao passo que um inquérito foi instaurado, no qual se relatavam que as práticas contábeis nada mais eram do que "porcarias" ou "coisa a ser jogada no lixo", no seu nível praticado no país americano; portanto, não podemos dizer que a ciência se mistura com esse tipo de coisa (e não existe nada de científico que seja imprestável).

Depois, vem a presença do IASB de alguma maneira copiando a estrutura do FASB, mas, igualmente, exercendo a atividade depois de 1972 e vindo à tona como relevante em 2003, permanecendo mais de três décadas "calado", quanto a interferir na normatização (sem uma repercussão coerente). Somente em 2003, segundo Carqueja (2011), passa a se ter a referência para a obediência do grupo internacional. Por que antes não havia o mesmo grau de importância, já que o grupo existia há mais de 30 anos? Essa pergunta pode levar a várias respostas.

A abordagem histórica é clara, ela não consegue detectar uma nítida simetria dos interesses científicos e éticos de maneira tangível no movimento da normatização americana, e muito menos da ênfase internacional; ao contrário, ela percebe o conjunto de contradições e de aspectos dicotômicos, paralógicos e, muitas vezes, aculturais dessas emanações regulativas de contabilidade, em muitos sentidos. 
Não só no contexto americano, como já observamos e tecemos comentários, mas também no âmbito do Comitê Internacional, contradições existiam, por exemplo, quanto à mesma norma de leasing editada em 1982, o que indicava a contabilização como ativo do mesmo contrato de arrendamento (que reproduzimos antes), depois aconselhando o seguinte: "um fabricante ou comerciante locador não reconhece qualquer lucro de venda ao entrar numa operação de locação porque ela não é a equivalente de uma venda" (IASB, 2010, s/p, numa primeira versão em 1982).

Ora, se o leasing deve ser contabilizado no ativo, como o locador, aquele que cede o arrendamento, não pode reconhecer o lucro nessa operação se ela não é equivalente a uma venda? Se o leasing está no ativo, é porque ele foi comprado e, se a sua contabilização for recomendada, como pode depois dizer que o arrendador não pode reconhecer os benefícios da operação, por não ser venda? Logo, é leasing no ativo como compra, e não o é ao mesmo tempo. Antagonismo claríssimo.

Mas, neste conjunto de posições, houve sim reflexões contrárias a tal marcha e, ainda, crítica de inúmeros acadêmicos e até de membros desses grupos; todavia, a vontade política prevaleceu muitas vezes sobre a verdade, o que prejudicou a estrutura contábil em corpo de normas, as quais eram alteradas à reveria por diversas vezes e foram, repetimos, improficientes para segurar a crise dos mercados, conforme a verificação histórica. Isso porque estavam ligadas às fraudes e manipulações de contas, que eram até permitidas em certos textos normativos sem carisma científico e sem robustez teórica.

Em seguida, procedemos a um segundo questionamento problemático: se houve relação da normatização americana com a internacional e se esta estava ligada à evolução dos usos dos princípios. A primeira parte da pergunta tem resposta positiva; a segunda, em essência, negativa e explicaremos o porquê. Primeiramente, vimos com clareza que foi em 2003, com os escândalos americanos, que se destacou a existência do IASB - antes havia apenas uma "pseudoexistência", muito tímida, podemos assim dizer. 
Todavia, é clara a posição que houve também acordos para o ajuste dessas normas, devido à influência americana, como D’avila (2008) afirmou:

Não se pode falar em convergência global de padrões contábeis se os Estados Unidos, maior mercado de capitais do mundo estiver fora dos planos. Pelo acordo até 2009, as Bolsas de Valores dos Estados Unidos teriam que aceitar demonstrações financeiras de empresas não-americanas, preparadas de acordo com os padrões contábeis emitidos pelo IASB, as IFRS (International Financial Reporting Standards) [...] sem que qualquer reconciliação ou explicação sobre diferenças para com os USGGAP fossem necessárias. (p. 8, grifos nossos)

Não poderia existir convergência sem a presença do país americano e suas influências normativas; da mesma forma, os padrões adaptados ao país foram também nele embasados, como notamos. Nesse sentido, o maior mercado do mundo não poderia se afastar do movimento "globalizante". Isso porque $25 \%$ das ações negociadas na Nyse são de empresas estrangeiras, o que favorecia um tipo de "acordo" nessa normatização internacional. Logo, em forma de imposição, sem apelo para as diferenças, como se o modelo fosse já o melhor absolutamente, embora estivesse em fase experimental (e no nível do mesmo experimentalismo encontrado antes na história americana).

No Brasil, "as propostas são a completa adoção das Normas Internacionais pelo CPC até o final de 2009" (Martins, 2008, pp. 5-7), e a finalidade de impor o modelo americano é evidente por parte dos adeptos da linguagem anglo-saxônica:

Querer impor um modelo contábil de origem anglo numa estrutura institucional e jurídica oriunda das tradições latinas do direito romano tem sido uma batalha muito difícil e não isenta de percalços [...] até que ponto deveremos nos deixar influenciar por esse entrave e renunciar a tudo que de mais moderno existe em matéria de tendências contábeis nos países contabilmente mais avançados? (Lopes e Iudícibus, 2004, p. 299) 
Logo, atenta-se para a qualidade das mesmas regras, nas quais, a partir da história e da análise atual, encontramos inúmeros defeitos na linguagem conceitual, o que nos faz apontar peremptoriamente as contradições.

Em 2008, mesmo após a crise de 2007 e com os efeitos desta, houve uma grande denúncia nos jornais mundiais que apresentavam a propagação da crise devido a uma norma internacional admitida como volúvel e à necessidade concreta de uso na sua pertinente operação reguladora de atualização do valor:

Bruxelas, 13 de outubro (Reuters) - A entidade responsável por definir padrões globais de contabilidade votou por flexibilizar as regras sobre contabilização de ativos a valor de mercado, disse um porta-voz nesta segunda-feira. As regras foram apontadas por críticos como um elemento que acabou exacerbando a crise financeira. [...]

Os membros do Conselho discutiram se deveriam alinhar as regras do IASB sobre contabilização a valor de mercado às medidas tomadas nos Estados Unidos, onde as autoridades já haviam decidido flexibilizar a regulamentação sobre o tema. (Reuters, 2008) ${ }^{6}$

Portanto, começa a se repetir - como dizia o chavão "quem não conhece a história está disposto a repeti-la" - o "ping-pong" de flexibilidade das normas devido à sua incapacidade de se manter em níveis científicos ou, ainda, devido à sua deficiência doutrinária. Se essas normas se regessem em tons apurados da ciência e da arte, obviamente, não seriam alteradas com facilidade.

0 ano de 2008 foi um cenário de crítica e réplicas sobre o mesmo tema volátil de discussão dos grupos normativos. $O$ professor Rogério Fernandes Ferreira e Antonio Lopes de Sá fizeram duras críticas na maior revista de circulação contábil de Portugal da então "Câmara dos técnicos de contas", hoje "Ordem dos Contabilistas Certificados", nas quais argumentavam que

6 Em outubro de 2008; por nós informada pelo professor Alexandre Alcântara naquela época, grifos nossos. 
o critério de valor justo (aplicável a 25\% das empresas portuguesas e pouco menos de $1 \%$ das brasileiras) era deficiente e apelante para uma fundamentação teórica apurada. No entanto, havia a defesa dele por parte de João Duque (2008), o qual argumentava que as empresas que quebraram pelo uso do valor justo tiveram nele uma "salvação", ainda que na bancarrota:

O justo valor não foi o mal, antes pelo contrário, ele veio possibilidade dar visibilidade e tornar transparente uma situação doentia, um mal a latejar, e que se não fosse ele se manteria ou se agravaria ainda mais com uma continuada atividade a desenvolver-se no mesmo sentido. $\mathrm{O}$ IASB, cedendo às pressões dos lobbies bancários, alterou então as normas aplicáveis [...] (p. 35)

Consequentemente, outra excêntrica afirmação estava contida sobre os grupos: "O IASB, cedendo às pressões dos lobbies bancários, alterou então as normas aplicáveis" (Duque, 2008, p. 35). Isso nos faz ainda responder que há concisa ligação da normatização internacional com a americana a se recordar o caso da empresa Robert Morris, de May, de Oxley e dos demais grupos no primeiro quinquênio que reproduzimos e cederam as pressões no mercado, e justamente, na década de 1970, com as intervenções das multinacionais de auditoria que guiaram a investigação do Accounting Establishment do Senado americano. Pode uma norma ser reconhecida como científica e sólida se é alterada por uma pressão de lobbies? Isso revela que a sua qualidade é duvidosa.

Por tal posição, houve até uma crítica da parte de Albuquerque (2009), que considerava muito estranho um grupo dessa natureza ceder às pressões de lobbies, ainda, no âmbito internacional e com a responsabilidade de produzirem normas estáveis para o mercado de capitais, para o mercado financeiro e para as empresas em geral.

Há, pois, coerente ligação da história das normas internacionais com as americanas, com a repetição até dos tristes fatos e, ainda, com a multiplicação da incidência de lamentáveis acontecimentos, de alteração constante de normas pela pouca estabilidade dos seus fundamentos, que levam o nome 
de "internacionais" ou de "fundamentais" na matéria de contabilidade, mas são totalmente flexíveis e híbridas.

Portanto, os problemas da cronologia da história americana que refutam um pleno acesso à ética e ao respeito à ciência ou técnica de nossa disciplina, com as influências nas normas internacionais, levam a um terceiro, que é o de qualidade dessas regras, devido às inúmeras dicotomias encontradas e à facilidade de dubiedade na interpretação do texto.

Normas não claras levam a fraudes e, ainda, pouco regulam o mercado e pouco interessam ao usuário; em resumo, pouca utilidade trazem ao ambiente empresarial e até ao nível de especulação. Como afirma um professor alemão pioneiro na literatura de fraudes: "qualquer alteração, a saber, da verdade constitui uma falsificação. Toda divisão da clareza significa uma simulação" (Jenny, 1944, p. 19).

Como os princípios adotados por esses grupos não eram válidos dentro das teorias e das doutrinas, obviamente, criaram vulgos inverídicos que causaram simulações e fraudes, com demonstração de informações falsas ou pouco claras.

Por isso, a segunda parte da segunda pergunta, em essência, não existiu, ou seja, não houve uma evolução sincera dos princípios da contabilidade em nível de prática de normatização; aliás, às vezes, nem se notava a presença deles com o passar dos tempos, mas de recomendações para as práticas habituais ou comuns. Dessa forma, demonstraram-se retrocessos pela absorção até dos defeitos existentes e de erros que resultavam em fraudes ou crimes financeiros.

Houve sim evolução dessas práticas, mesmo com as mazelas, o que fez com que as normas passassem por um nível de "experimentalismo constante", como se não houvesse base científica para se lastrear. 
Com efeito, dentro dos questionamentos levantados ao início deste artigo, sobre a história da normatização americana com ênfase na mundial, podemos resumir o seguinte:

1. os Estados Unidos foram proeminentes na normatização (Franco, 1988);

2. a divulgação da normatização contábil foi regulada por grupos que exigiam um predomínio de interesses sem base científica e com muita transitoriedade dos conteúdos (Silva, 2009; Sá, 2003);

3. depois de 2003, para se refrearem fraudes, aderiu-se à necessidade de regulação ou à padronização de balanços (Carqueja, 2011).

Portanto, é de se concluir que mesmo os Estados Unidos sendo pioneiro na política contábil, não quer dizer que são o melhor país em nível de contabilidade ou que tal processo tenha sido o de maior qualidade. E é obvio que tudo tenha culminado na tentativa mundial de regulação, não só por questões econômicas (por ser este o pulmão mercadológico do mundo), mas também por questões históricas e de influências, como vimos.

Ao mesmo tempo, procedemos a uma pergunta: será que houve fidedignidade no processo? Tudo nos leva a dizer que não necessariamente. No movimento saxônico, houve sim acordos e presenças de grupos que não davam cadeiras explicitamente para os especialistas em contabilidade. Isso é facilmente percebido na história, quando:

1. as primeiras normas foram incompetentes para orientar as conclusões que se deveriam ter dos balanços (primeiro momento regulativo em relação ao mercado financeiro);

2. as normas para os mercados foram incompetentes para segurar a Grande Crise, acoplada com o acordo de grupos que não levavam à tona a sinceridade científica (segundo momento da história do movimento normativo americano); 
3. as comissões de normas faziam acordos com grupos que mantinham panfletagem normativa ineficaz e contraproducente aos princípios de contabilidade, com alterações constantes;

4. as comissões e os grupos da profissão americana foram ineficazes para manter a simetria do mercado, misturando a contabilidade com outras disciplinas, ora extraindo das outras o subsídio para a nossa, ora levando esta a uma finalidade restrita a um instrumentalismo singelo, colocando-a em uma realidade fora do seu objeto e em outro objeto pertencente à economia;

5. os cientistas de contabilidade americana não eram definidores diretos do processo;

6. os grupos de regulação desde a década de 1930 e com a criação de outros na década de 1970 não refrearam outra crise;

7. mesmo com a presença de grupos normativos e de normas internacionais, bem como a existência em três décadas desses grupos, não existiu uma refração das fraudes em 2003;

8. mesmo com o apelo às normas internacionais, houve crise de mercado em 2007, o que levou à alteração dessas regras;

9. segundo denúncias, a causa para a crise está diretamente ligada à má condição das normas;

10. existe uma permutação de normas pelo gosto de lobbies, ao passo que se definem como científicas, contudo são empíricas, sem palpabilidade, com trocas contínuas e a utilização de um experimentalismo que causa prejuízos econômicos indeléveis e irreversíveis, ou com sequelas permanentes, contidas e relevadas na história, naquilo que já está consagrado em doutrina e teoria sólida de contabilidade; todavia, não se nota a sua presença no corpo dessas regras, é o corpo teórico-doutrinário que forma todo o arcabouço 
básico da contabilidade ligado aos princípios, aos conceitos e aos fundamentos, dando origem à sua estrutura geral de informação e conhecimento conceitual.

Tudo isso colimou num movimento globalizante, porém não diretamente técnico, pois mesclou a atual posição contábil na forma, contudo sem um apelo ético à fidedignidade e à lisura do processo.

O que se revela na história dos grupos já está comprovado e evidente. Agora, o que será do futuro dessa história ou da futura história desse movimento é uma outra pergunta que não será respondida por nós.

\section{Conclusão}

Concluímos que a história do movimento normativo americano teve inúmeros fatos marcantes e, de alguma maneira, produções que influíram na normatização mundial, pois foi o primeiro e proeminente país a preconizarse na política contábil e na elaboração dessas regras.

Não se pode admitir, pela história dos fatos, que a normatização em processo americano favoreceu a qualidade da informação contábil ou o estribo dos princípios, considerando as doutrinas e teorias existentes no arcabouço da contabilidade e na totalidade de dimensionamento da fenomenologia uniforme. Isso porque inúmeros fatores como o uso de política fraudulenta com avareza, os acordos ilícitos de especulação, o poder, a manipulação, a falta de desenvolvimento da cultura básica, foram os baluartes das normas emitidas pelos seus principais grupos de regulação, ainda com influência nítida nos internacionais, tendo como ápice as crises mundiais e as ondas de fraudes ligadas a empresas voltadas ao processo.

Enfim, entendemos que o estado dessa história designou contrastes, disparates e máculas, no que se refere à ética, à ciência e à qualidade informativa, o que leva a prejuízos na fidedignidade da informação com crises mundiais, problemas de mercados e ondas de fraudes, sem base nos 
princípios. Em consequência, o problema de sustentação dessas regras se mantém, o que provoca certa aceitação, mas sem indagação sobre a forma privilegiada no processo, descurada do correto, da lógica de excelência da relevação, não somente no contexto americano, mas também no mundial, disposta na informação verdadeira, fazendo-nos questionar o que será do futuro da história desse processo.

\section{Referências}

Albuquerque, F. H. F. de. (2009). Porque não há duas opiniões sem três... Revista da Câmara dos Técnicos Oficiais de Contas, ano Ix(107), 26-27.

Bilas, R. A. (1976). Teoria Microeconômica. Rio de Janeiro: Forense-Universitária.

Carqueja, H. O. (2011). Entrevista. Revista da Ordem dos Técnicos Oficiais de Contas, ano XI(111).

Casella, C. L. G. (2010). Un interesante cuestionario relativo a la posible medición del llamado fair value o valor razonable. Revista de Contabilidad y Auditoria, 16(31), 38-58.

Cravo, D. J. da S. (2010). Entrevista. Revista da Ordem dos Técnicos Oficiais de Contas, ano $\mathrm{x}(119), 6-13$.

Cravo, D. J. da S., Jesus, J. R. e Antão, A. (2010) Ativos fixos tangíveis: venda e relocação seguida de revalorização. Revista da Ordem dos Técnicos Oficiais de Contas, ano XI(129), 23-27.

D’Avila, M. Z. (2008). Convergência entre os USGAAP e IFRS: uma transição lenta? Boletim do conselho regional de contabilidade do estado de São Paulo, ano $\operatorname{xxxix(168),8-11.~}$

Duque, J. (2008). Em defesa do valor justo. Revista da Câmara dos Técnicos Oficiais de Contas, ano Ix(105), 34-35. Recuperado de https://www.occ.pt/fotos/ downloads/files/1229698585_34e35_contabilidade.pdf

Ferreira, R. F. (1981). Reflexões sobre princípios contabilísticos e ajustamentos monetários em períodos de inflação. Lisboa: Apotec.

Ferreira, R. F. (1983). Normalização Contabilística (dissertação de doutoramento). Coimbra: Livraria Arnaldo.

Ferreira, R. F. (2009a). Considerações sobre "Passivo". Jornal da Apotec, ano $\operatorname{xxXIII}(385)$. 
Ferreira, R. F. (2009b). Contabilidade — critérios valorimétricas. Revista da Câmara dos Técnicos Oficiais de Contas, ano x(110), 45-51.

Ferreira, R. F. (2010). Comentários às NIc. Revista da Ordem dos Técnicos Oficiais de Contas, ano xi(esp.).

Franco, H. (1988). A evolução dos Princípios Contábeis no Brasil. 13º Congresso Brasileiro de Contabilidade. Cuiabá: CFC.

Hendriksen, E. S. e van Breda, M. F. (1999). Teoria da Contabilidade. São Paulo: Ed. Atlas.

International Accounting Standards Board [IASB] (2010). Norma internacional contabilística $n^{\circ} 17$ - locação financeira por fabricantes ou comerciantes [Página web]. Gesbanha - Gestão e Contabilidade. Recuperado de https:// gesbanha.com/?option=com_content $\&$ view $=$ article\&id $=206 \% 3$ Anic$17 \&$ catid $=82 \% 3$ Anormas-internacionais-contabilisticas \&Itemid $=321 \&$ sho wall $=1$

Iudícibus, S. (2000). Teoria da Contabilidade. São Paulo: Ed. Atlas.

Iudícibus, S. (2003a). Por uma nova estrutura conceitual básica da Contabilidade. Boletim do Ibracom, ano Xxiv, 1-14.

Iudícibus, S. (2003b). Caminhos e descaminhos da contabilidade. Revista Paulista de Contabilidade, 8(25), 32-40.

Jenny, E. G. (1944). Los fraudes en contabilidad - cómo se practican y descubren (J. Valls, Trad.). Barcelona: Ibéria-Joaquim Gil.

Levene, R. (1954). História das Américas. São Paulo: Ed. Brasileira Ltda.

Lopes, A. B. e Iudícibus, S. (2004). Teoria Avançada da Contabilidade. São Paulo: Ed. Atlas.

Martins, E. (2008). Entrevista: Adesão às NIC ajuda no nível de respeito com os países verão o Brasil. Boletim do conselho regional de contabilidade do estado de São Paulo, ano $\operatorname{xxxix(168),~56-58.~}$

Masi, V. (1945). Statica Patrimoniale. Padova: Casa Editrice Dottore Antonio Milani. Myer, J. N. (1972). Análise das Demonstrações Financeiras. São Paulo: Ed. Atlas.

Nepomuceno, V. (2002). A queda da Contabilidade Gerencial e a ascensão da fraude contábil nos Estados Unidos. Boletim do Ibracon, ano Xxiv(285).

Nepomuceno, V. (2003). Qual é a massa atômica de uma unidade de custo? Revista Brasileira de Contabilidade, (140).

Nóbrega, V. L. da. (1959). O latim do Ginásio. São Paulo: Editora Nacional. 
Kant, E. (s/d). Crítica da Razão Pura (J. R. de Mereje, Trad.). Rio de Janeiro: Ediouro. Parma, H. (2002). O caso da escola contábil anglo-saxônica. Revista Mineira de Contabilidade, ano III(8), 18-19.

Paulo, E. (2002). Comparação da estrutural conceitual de contabilidade financeira: experiência brasileira, norte-americana e internacional (dissertação de mestrado). João Pessoa: Programa multi-institucional e inter-regional de pós-graduação em Ciências Contábeis.

Poincaré, H. (1924). O valor da Sciencia. Rio de Janeiro: Livraria Garnier.

Reuters. (2008, outubro 13). IAsB também flexibiliza [Página web]. Contabilidade Financeira. Recuperado de https://www.contabilidade-financeira.com/2008 /10/iasb-tambm-flexibiliza.html

Sá, A. L. de. (1953). Princípios e Preceitos de Contabilidade Industrial. São Paulo: Atlas.

Sá, A. L. de. (1994a). Ajustes e Valorimetria Contábil. Revista Brasileira de Contabilidade, ano $\operatorname{xxIII(86),~30-33.~}$

Sá, A. L. de. (1994b). Lucro Inflacionário: expressão fantasiosa. Revista Brasileira de Contabilidade, ano XxiII(90), 14-16.

Sá, A. L. de. (1997). O conceito mais moderno de atualização de Balanço. Revista Brasileira de Contabilidade, ano xxvi(106), 64-67.

Sá, A. L. de. (2000). Princípios Fundamentais de Contabilidade. São Paulo: Ed. Atlas.

Sá, A. L. de. (2003). Bases das Escolas Européia e Norte-Americana, perante a Cultura Contábil e a Proposta Neopatrimonialista. Revista de Contabilidade do Rio Grande do Sul, (2), 7-24.

Sá, A. L. de. (2008). “Justo Valor” e crise nos mercados. Revista da Câmara dos Técnicos Oficiais de Contas, ano $\mathrm{Ix}(103), 32-33$.

Sá, A. L. de. (2009). Justiça de valor e justo valor. Revista da Câmara dos Técnicos Oficiais de Contas, ano x(111), 47-49.

Sá, A. L. de. (2010). Realidade sobre as normas internacionais de contabilidade. Revista da Ordem dos Técnicos Oficiais de Contas, ano XI(esp.).

Silva, R. A. C. da. (2007). Evolución Doctrinal del conocimiento contable y tendencias actuales en los tiempos modernos. Revista Internacional Legis de Contabilidad \& Auditoria, (34), 153-200. 
Silva, R. A. C. da. (2008). Aspectos das finanças empresariais e a sua dinâmica - pontos importantes e proposta de uma nova fórmula. Revista Contabilidad $y$ auditoria, 14(28), 83-101.

Silva, R. A. C. da. (2009). Evolução doutrinária da Contabilidade - Epistemologia do princípio patrimonial. Curitiba: Juruá.

Silva, R. A. C. da. (2010). Aproximación al estudio de la normalización contable internacional, desde la escuela neopatrimonialista. Revista Internacional Legis de Contabilidad \& Auditoria, (41), 95-140.

Teichman, J. e Evans, K. C. (2009). Filosofia. (L. Sano, Trad.). São Paulo: Madras. 